\title{
Validation of Extended Theory of Reasoned Action to Predict Mobile Phone Money Usage
}

\author{
Odoyo Collins Otieno ${ }^{1, *}$, Samuel Liyala ${ }^{1}$, Benson Charles Odongo ${ }^{2}$, Silvance Abeka ${ }^{1}$, Solomon $\operatorname{Ogara}^{1}$ \\ ${ }^{1}$ School of Informatics and Innovative Systems, Jaramogi Oginga Odinga University of Science and Technology, Bondo Town, Kenya \\ ${ }^{2}$ Department of Special Needs Education and Early Childhood Development, \\ Jaramogi Oginga Odinga University of Science and Technology, Kenya
}

Copyright $\odot 2018$ by authors, all rights reserved. Authors agree that this article remains permanently open access under the terms of the Creative Commons Attribution License 4.0 International License

\begin{abstract}
Theory of Reasoned Action (TRA), postulated by social psychologist, has been established to be relevant in guiding Information Systems studies. The theory resulted from attitude research using the Expectancy Value Models. Therefore, TRA can be more effective if extended with additional determinants/constructs of systems use. The purpose of this study was to validate the additional constructs expected to strengthen TRA. Both qualitative and quantitative research methods were used in compilation of this paper. Additional determinants have therefore been validated using correlation and are illustrated in this article to demonstrate their effects on technology use in an Information Systems discourse. To achieve this, the authors used the findings from a study that was conducted in setting that presented rural urban characteristics, varied social economic characteristic as well as the varied age sets. The paper puts clearly the possibility of applying the theory of reasoned action in an information systems discourse, with additional constructs, giving birth to the Extended Theory of Reasoned Action.
\end{abstract}

Keywords Information Systems, Theory of Reasoned Action, TRA, Extended Theory of Reasoned Action

\section{Introduction}

Ajzen and Fishbein formulated the Theory of Reasoned Action (TRA), by 1980. This resulted from attitude research using the Expectancy Value Models [1] [2]. They did this formulation of TRA after trying to estimate the discrepancy that existed between attitude and behavior. The fundamentals of the TRA come from the field of social psychology. Social psychologists attempt, among other things, to explain how and why attitude affects behavior, was very important. This is equally very important in mirroring Information Systems studies. That is, how and why people's beliefs change the way they act. Psychologists argued about what should make up the term attitude. Social psychologists suggest that attitude includes behavior and cognition, and that both attitude and behavior, are positively correlated. This is the reason why Information Systems study should adopt Theory of Reasoned Action in guiding technology use studies. To make TRA more effective, there is need to add additional constructs and that was the basis of this paper. The paper therefore identified other constructs that influences technology acceptance and hence use, and in this context factors affecting mobile phone money use, and further validating them using correlation analysis.

\section{Materials and Methods}

\subsection{Research Approach}

The research approach adopted was qualitative in nature because it was appropriate in understanding the dynamics of this study subject area. This approach was relevant to the study based on its interpretive nature as well as its abilities to generate and address multiple realities that were eminent in the study context. The strength of qualitative research in this study was its ability to provide complex textual descriptions on mobile phone users' opinions on mobile phone money use. As an approach, it provided information about; contradictory behaviors, beliefs, opinions, emotions, and relationships of individuals.

Qualitative methods are also effective in identifying intangible factors, which include social norms, socioeconomic status, gender roles, ethnicity, and religion, whose role in this paper may not be readily apparent. The findings from qualitative data can often be extended to people with characteristics similar to those descried in this paper as study population, which aids in gaining a rich 
and complex understanding of a specific social context or phenomenon and this typically takes precedence over eliciting data that could be generalized to other geographical areas or populations [3].

The final part of validating the factors established to have effect or to influence mobile phone money use was quantitatively carried out. Even though the paper is major qualitative, quantitative approach was most convenient in validating the constructs, owing to the strength that exists in dealing with the numbers to present a point.

\subsection{Research Design}

This paper is based on ethnography research design due to its usefulness and appropriateness for a study of a context like this. Ethnography, emerging from anthropology, and adopted by sociologists, is a qualitative methodology that lends itself to the study of the beliefs, social interactions, and behaviors of small societies, involving participation and observation over a period of time, and the interpretation of the data collected [4]. It is very time consuming type of research, however, its main benefit is its depth, and therefore the contribution of rich insight to the subject being studied. One weakness is that it lacks breadth, as the focus is typically on one particular situation or phenomenon, leading to a criticism of lack of generalizability [5]. Also, the main data collection technique is participant observation [6].

Ethnography data consists of unstructured accounts and the analysis, which provides interpretation of meaning, and is done by the researcher, using observation, description and explanation [7].

Further, this paper blended ethnography design with correlation, especially when it came to validation of the key constructs that were established to be necessary in strengthening TRA, and that eventually led to the formation of the extended TRA.

\subsection{Location of the Study}

This study that this paper is based on was conducted in Homa Bay Region, covering an area of $1,169.9 \mathrm{Km}^{2}$, and comprising of Homa Bay Town, Ndhiwa and Rangwe sub counties, in Homa Bay County in the Republic of Kenya. The area is located in South Western Kenya along Lake Victoria.

The study area enjoys the presence of five major banks namely: Barclays Bank, Kenya Commercial Bank, Cooperative Bank, Post Bank and Equity Bank. These banks are based in Homa Bay Town and Ndhiwa Sub Counties, where as Rangwe lacks the presence of any bank [8]. The rest of trading centers in the study area are served largely by Microfinance Institutions, SACCOs, and presently more than 60 banking agents [8]. Mobile money transfer services and agency banking is expected to grow very rapidly to expand access to banking in the area. The reason for conducting a study in this area was the fact the Homa Bay Region portrayed the desired characteristics that this study was looking for. The main characteristics it portrayed were rural and urban settings, middle-income earners and low-income earners, educated and non-educated individuals, all exist in this region.

\subsection{Target Population, Sampling Technique and Sample Size}

\subsubsection{Target Population}

Study population for this study was 167,358 people owning mobile phones in Homa Bay region of Homa Bay County as illustrated in table 1. This is a fraction of 325,453 people who have access to mobile phones [9], or total population, 366,620 people in Homa Bay region (Homa Bay Town, Ndhiwa and Rangwe sub-counties) according to 2009 Kenyan census results [10]. The same statistics indicated that a total of 856,946 people in Homa Bay County had access to mobile phone services, while 440,021 people owned mobile phones [10]; compared to the total population of Homa Bay County that was $\mathbf{9 6 3 , 7 9 4}$ people [9].

To ensure representative data, gender and age consideration was taken into account while selecting the informants. The population statistics for Homa Bay region as well as Homa Bay County is summarized in table 1.

Table 1. Homa Bay Region Access to Mobile Phone Services Population

\begin{tabular}{cccc}
\hline & Total Population & $\begin{array}{c}\text { Access to Mobile } \\
\text { Phone Services }\end{array}$ & $\begin{array}{c}\text { Owning Mobile } \\
\text { Phone }\end{array}$ \\
\hline $\begin{array}{c}\text { Homa Bay } \\
\text { Region }\end{array}$ & 366,620 & 325,453 & 167,358 \\
\hline
\end{tabular}

Source: KNBS, 2014a and KNBS, 2014b

\subsubsection{Sampling Technique}

This study used a triangulation of probability and non-probability sampling techniques, specifically, Stratified sampling and purposive sampling techniques [11] [12].

Since the participants to this study possess heterogeneous characteristics, stratified sampling was used when putting the target group into homogeneous subgroups for the effective process of data collection. The groups were categorized into three sub-counties, giving the initial three strata. In the three sub-counties, Homa Bay sub-county represented urban characteristics of mobile phone users, while both Ndhiwa and Rangwe sub-counties represented rural characteristics of users. This led to the next level of stratification, which categorized the study population into gender (male or female) and age (youth or the old).

Purposive sampling on the other hand was used to select the informant with desirable characteristics for this study, notably, those from the study area who enable the researcher to obtain divergent views about mobile phone users' opinions and views on mobile phone money use. The sampling techniques were used to select the informants for both the interview and focus group discussions, from 
each of the last set of strata (male, female, youth and the old).

\subsubsection{Study Sample Size}

According to Flick [13], Morse [14] and Strauss \& Corbin [15], Sample sizes in qualitative research should not be too large that it is difficult to extract thick and rich data. The sample should also not be too small that will make it difficult to achieve data saturation, theoretical saturation.

Kothari [16] argues that, an optimum sample is one that fulfills the requirements of efficiency, representativeness, reliability and flexibility. The study adopted a triangulation of stratified and purposive sampling technique, to select mobile phone owners in the study area with the desired characteristics that was most likely going to yield the desirable results for this study. A total of 48 participants were selected for both the focus group discussion and interview. Out of the 48 participants, 16 participants were used for semi-structured interviews that were conducted to help in further identifying the main themes that were used in the focus group discussions. The other 32 participants were targeted for focus group discussions. The researcher conducted conduct 4 focus group discussions, one each for Ndhiwa and Rangwe sub-counties and two for

Homa Bay Town sub-county. Each focus group discussion consisted of 8 participants (male youth, old male, female youth and old female). Table 2 illustrates clearly the sample.

\subsection{Data Collection Instruments}

\subsubsection{Semi-structured Interview Guide}

Interview schedules were used to collect data on mobile phone users' capabilities on mobile phone money use.

According to Kombo and Tromp [17], a semi-structured interview gives in-depth information gathered by use of open-ended questions. Quinn [18] agrees with Kombo and Tromp on the purpose and nature of semi-structured interviews. This study used face-to-face interviews to collect information from all informants.

\subsubsection{Focus Group Discussions}

The study used 4 focus groups of 8 participants per group. The 8 participants were in line with gender consideration as well as age consideration. The rural and urban settings were also considered in this study. Kombo and Tromp [17] posit that special pre-determined criteria should be used in selecting focus group participants. The interviewer created a supportive environment, asking focused questions to encourage discussion and the expression of differing views and opinions of the users with respect to the use of mobile phone money services.

\subsubsection{Participant Observation}

Participant observation played an important role when examining opinions of mobile phone users on mobile phone money use. Compared to other qualitative methods of data collection, participant observation helped in explaining qualitative findings by providing the contextual meaning behind other data generated by interviews and focus group discussions as reiterated [19]. Participant observation was applied at the same time as other forms of data collection, as well as the analysis of secondary data. The participant observation was further used to explain apparent contradictions in other data as also seen in the works of Stephen Koester [20].

Table 2. Sample size

\begin{tabular}{|c|c|c|c|c|c|c|}
\hline \multicolumn{6}{|c|}{ FOCUS GROUP DISCUSSION SAMPLE SIZE } & \multirow{3}{*}{ TOTAL } \\
\hline & & \multicolumn{2}{|c|}{ MALE } & \multicolumn{2}{|c|}{ FEMALE } & \\
\hline & & YOUTH & OLD & YOUTH & OLD & \\
\hline URBAN & Homabay Town & 4 & 4 & 4 & 4 & 16 \\
\hline \multirow{2}{*}{ RURAL } & Ndhiwa & 2 & 2 & 2 & 2 & 8 \\
\hline & Rangwe & 2 & 2 & 2 & 2 & 8 \\
\hline \multicolumn{2}{|c|}{ TOTAL } & 8 & 8 & 8 & 8 & 32 \\
\hline & & \multicolumn{4}{|c|}{ INTERVIEW SAMPLE SIZE } & \multirow{3}{*}{ TOTAL } \\
\hline & & \multicolumn{2}{|c|}{ MALE } & \multicolumn{2}{|c|}{ FEMALE } & \\
\hline & & YOUTH & OLD & YOUTH & OLD & \\
\hline & Homaba Town & 2 & 2 & 2 & 2 & 8 \\
\hline & Ndhiwa & 1 & 1 & 1 & 1 & 4 \\
\hline & Rangwe & 1 & 1 & 1 & 1 & 4 \\
\hline \multicolumn{2}{|c|}{ TOTAL } & 4 & 4 & 4 & 4 & 16 \\
\hline \multicolumn{2}{|c|}{ GRAND TOTAL } & 12 & 12 & 12 & 12 & 48 \\
\hline
\end{tabular}




\section{Discussion}

\subsection{Factors Influencing Mobile Phone Money Use}

Field interview data revealed some of the factors that mobile phone users perceived to influenced mobile phone money use in the study area. These factors differed from one setting to the other. Even though most of the users acknowledged that mobile phone money was in did useful even in the rural communities, especially when an individual do not have cash, and that it provided flexibility, they still had a strong opinion that it was a technology meant for those who were either educate or wealthy. The educated in the point of view of some of the informants would be able to navigate the instructions and procedures of usage with a lot of ease, while the wealthy would have no difficulty of purchasing the mobile phone handset even the most sophisticated ones.

\subsubsection{Literacy as a Factor}

The study established that the rural communities still perceived mobile money payment as a technology meant for those who were educated. The study established that the rural poor in their point of view that, only those who were more educated were the ones who were either ready to make good use of mobile phone payment innovation in the rural communities. They perceived the process and procedure followed when transacting using mobile phone money to be challenging and required some level of education to be able to easily cope.

Related to literacy was language barrier which was yet another reason that led to low use of mobile money services in the study area, especially when one sends money to a wrong person, and the only way out of retrieving the amount back involves contacting customer care whom they either have to address in Swahili or English languages only, a factor that hinders many who found themselves in such a circumstance, from seeking reversal of transactions. Such users therefore perceived mobile phone money services to be insecure for their use. This meant that most of such individuals would in many cases fail to follow up for such wrong transactions to be reverted due to language barrier, as they could neither speak English or Swahili languages used by customer care, and this further negatively influenced their opinions about mobile phone money use negatively. When such challenges takes place, in many cases mobile phone money agents keeps off and advices the users to contact customer service on their own, as established by the study making such user to further perceive this technology to be unfriendly to them.

\subsubsection{Economic Status as a Factor}

The study also established that the rural communities still perceived mobile money payment as a technology meant for those who were of relatively higher economic status in the society. The study established that the rural poor in their opinion that, only those who were of relatively higher economic status in the society were the ones who were either ready to make good use of mobile phone payment innovation in their communities. Their perception was that the wide range of services offered by mobile phone money service ware only available on smart phones that they perceived to be costly and could only be acquired by those who were relative of higher economic status. To them, economic status was a necessary determinant to extensive use of mobile phone money services.

According to the theory of reasoned action [21], the most accurate determinant of behaviour is behavioural intention and the direct determinants of people's behavioural intentions are their attitudes towards performing the behaviour and the subjective norms associated with the behaviour. Their perception about mobile phone use, therefore influence their behavioural intention to use this technology.

\subsubsection{Possession of National Identification Card as a Factor}

Another factor that was established to influence mobile phone money utilization, especially, in the rural settings was lack of the national Identification (ID) cards especially by most women below the age of 30 years in the rural communities of Kenya majorly. Since it was a requirement by Communications Authority of Kenya; a Kenyan telecommunication regulator; that all Mobile Network Operators (MNO), register all their subscribers and this process of registration required an individual to be in possession of national ID card, and thus, those without national ID cards technically found themselves excluded from this innovation. Further, to have access to mobile phone money services offered by any of the MNOs, you were required to register separately for the service. This process equally required the intended users to be in possession of national ID cards. Therefore, national ID card was a major factor that negatively influenced mobile phone money utilization, majorly in the rural communities according to the perception mobile phone users' and potential users', especially young women were not in possession of these valuable documents. National ID cards was therefore a facilitating condition for use of mobile phone money services in this case. This therefore illustrated, that facilitating conditions for increased use of mobile money in the study area, more so, the rural communities were still very low. Possession of a national ID card was in deed a necessary facilitating condition for a potential user who intended to register for mobile phone money services.

\subsubsection{Information/Knowledge on the Elements of Mobile Phone Money Services}

The paper established that most of the mobile phone users had inadequate information on mobile phone money 
and the elements of mobile phone money. Majority of the users mostly, in the rural setting, were mainly aware of the element of sending and receiving money through mobile phone. However, they were more surprised when they heard during FGDs from other participants, elaborating the other elements of mobile phone money services such as buy goods and pay bill elements. What was more surprising to them was that even their mobile phones, for those who had registered for mobile money services such as M-Pesa, Airtel money among others, had access to such elements. This was therefore a proof that many users were unaware of the full potential of the technology that they had. This meant that there were those potential users who failed to utilize mobile phone money technology, simply for lack of awareness of existence of such technological innovations. They perceived their mobile phones to be only capable of making calls, sending short messages as well as only doing remittances of money. Therefore studies on technology or innovation use require the researcher to include user awareness of the new technology or innovation.

Contrary to those who did not have access to this technology, some of the users had access, but were not aware of the wide ranges of services that their mobile phone money technology could offer to them. This too was another major factor that negatively influenced mobile phone money use in the rural parts of the study area. This was similar to some of the concerns raised by Suri and William [22], in their study conducted in Kenya, involving $M$ - Pesa users and non - users to establish the profile of M - Pesa's early adopters and customer usage patterns. Their study established that the average $\mathrm{M}$ - Pesa user was, in comparison to non - users, was twice as likely to have a bank account, wealthier, more literate, and better educated. This showed that a greater majority of the rural poor community were not aware of the existence certain innovations, even those that were available in the gadgets that they already possessed. It is therefore quite important to include Awareness of Innovation as a variable when conducting studies on technological innovation.

Inadequate information on mobile phone money was also major challenge facing the users in the study area from utilizing mobile phone money service, especially in the rural communities. This challenge influenced on whether to use or not to use mobile phone money services in the study area. Most of the people claimed to have better understanding of mobile money use, but on further interrogation, the researcher established that they were mainly aware of the aspects of sending and receiving money (remittances). Most of the mobile phone money users lacked the information that mobile phone money could as well be used to buy goods through the use of till numbers and payment of utility bills as long as the utility service provider had a business number from MNOs.

According to Kenya's Economic Survey of the year 2003 [23], the major Information Systems and mobile technology challenges in the Kenya consist of poor and inadequate information systems, inadequate IT infrastructure, limited skills in ICT, lack of appreciation of ICT, technology weaknesses exhibited by heavy reliance on inappropriate and obsolete technology, lack of skills on modern technology, lack of awareness of the changing technology, poor dissemination mechanisms between and among the various levels of enterprises, and poor technology linkages between the private and public sector institutions. This concurs with the findings established by this study that clearly showed lack of awareness on the wide range of services offered by mobile phone money services. Majority of mobile phone money users in the study area were only aware of aspects of remittances. However, when it came to other services such as the use of Pay Bills and Buy Goods services, quite a number were surprised to realize that even their own mobile phones had the sane capabilities. This showed lack of awareness in the study area on the constantly changing technologies. Many even got stuck to obsolete methods of transaction of the emerging technologies that offered numerous benefits. This was coupled by the limited skills and knowhow by the people in the study area, to navigate various services offered by their mobile phones in order to be aware of the wide range of services that they could have access to.

\subsubsection{Social Pressure as a Factor}

This paper also finds social pressure as a factor that positively influences behavioral intention. Many users readily utilized mobile phone money to send or to receive money in an attempt to be like their friends or relatives who had embraced the innovation. The mobile phone users' perception that, those who had embraced mobile phone money technology appeared superior in some way, exerted pressure in many following the trend. This was one of the major reasons that led to many people in the study locality embracing mobile phone money for remittances purpose. This has similarity to issues raised on remittance in Kikulwe, Fischer and Qaim study [24]. Their study analyzed micro level impacts using panel data from smallholder farmers in Kenya and established that mobile phone money use had a large positive net impact on household income. One important pathway according to the researchers was through remittances, which contributed to income directly but also helped to reduce risk and liquidity constraints of such users in the rural context.

The study also established that there were other challenges that Faced Mobile phone money that also influenced use, and was established to be real especially among the rural communities. There was a legitimate concern that some aspects of mobile phone money services were not popular, not only within the rural areas, but even within urban areas. For that reason, fewer urban dwellers used mobile phone money. Some of the challenges that had led to this according to the findings included little awareness about mobile money, lack of support in vernacular languages, and, perhaps most crucially, security 
issues for both customers and regulators. According to The World Bank working paper No. 146 "Integrity in Mobile Financial Services" established that security concerns were at the center around customer identification, data protection, the ability to disguise mobile transaction totals, the speed with which illicit transactions can be carried out, and the level of regulation of the service providers. These limitations could be expected to be on the decline as new technologies evolve and existing ones establish their credibility. Even though mobile banking was especially valuable for rural regions across the world because of the lack of alternatives, its delivery depends upon overcoming several bottlenecks across the varied societies. The most pressing of these was meeting the prerequisite of mobile network coverage. Also, physical security concerns were more acute in rural areas, especially with the use of agents. Proper measures needed to be placed at the kiosks where physical transactions take place, due to the problems associated with crime and bribery. Even though transactions could be cashless, however, hard cash still needed to be available for customers, especially those who received money from friends and relatives and would like to withdraw. This was the reason why security was needed to be a priority, although it might be particularly difficult in more remote areas.

\subsubsection{Security as Factors}

In Homa Bay region, there existed a number of challenges that prohibited or discouraged potential mobile phone user, from using mobile phone money services as established by the study. These challenges were mainly common in the rural areas than they were in urban areas. In the rural areas, remittances were no longer going to be more secure in the coming days to the users' who were illiterate. Most of these users' were unable to effectively navigate through the process of operating their mobile phones to either send or withdraw money from mobile money agent. At the time of this study, most of them would therefore resort to disclosing their secret PIN numbers for their mobile phone money service to mobile money agent making their money in mobile phones unsecure.

Mallat [25] in his study established that Finnish consumers found SMS based payments to be complex and slow to use. SMSs were heavily criticized because the message formats are often complicated, the service numbers are difficult to remember and instructions can be hard to find. Therefore Mallat suggested that SMS was not the best possible technology used for mobile payments in Finland. This was also true to the study area, especially the rural parts, where there were a number of users who were illiterate. Such users were uncomfortable with the technology as it locked most of them out, and therefore, the reason as to why they disclosed their secret PIN numbers to mobile phone money agents or other people such as their relatives, an act that compromised on the security of their mobile money.

\subsubsection{Trust as a Factor}

The study established that most of the mobile phone users within the rural areas would always resort to disclosing their secret PIN numbers for their mobile phone money service to mobile money agent, or those people that they would consider trusted. This was due to illiteracy and would always seek for assistance from such people from time to time. They therefore perceived all mobile phone money agents as those who could be trusted. In such a circumstance, aspect of trust stood a chance of being abused by those who might be of ill motive. To carb this, many users would be required to be knowledgeable. This would mean that being knowledgeable, to the level where one would easily be able to navigate mobile phone money with ease, would become a significant facilitation condition that would positively influence behavioural condition to use the innovation.

Drawing from representative survey data, conducted by Porteous [26], where mistrust and unawareness were among the primary reasons South Africans might choose not to use mobile banking as well as mobile money. According to Porteous, in South Africa majorly mistrust and unawareness were the primary reasons that led to low use of mobile banking as well as mobile phone money services. This would soon likely to be the scenario in the study area, especially at time when a number of mobile phone money users who would be illiterate would have fallen prey to malicious agents. Many users would therefore refrain from the use of this technology.

Mallat [25] in a study suggested that SMS was not the best possible technology used for mobile payments in Finland, which was also a similar situation to the study area, especially the rural parts, where there were a number of users who were illiterate, and as such were uncomfortable with the technology as it locked most of them out. This led to most of these users disclosing their secret PIN numbers to mobile phone money agents or other people that they would feel are trusted. This kind of approach in receiving the services offered by this technology, on the event of fraud, however, small the fraud may be, would be capable of discouraging a number of users from using mobile phone money services. This would have the implication of them trying to get the same services through other avenues or means. This therefore becomes trickier to balance on whether to discourage agents from guiding customers, and having them guide customers during transaction.

Citibank report [27] puts it that, mobile phone money as a product was much more complicated to sell than airtime. Selling airtime was quick and simple for the user to understand. By contrast, a mobile money agent would most likely have to answer a number of user questions. That was, they might even need to complete a transaction on behalf of the user to demonstrate how it was done, a move that require trust between the agent and the user. This meant that MNOs had to invest in agent training up front [27]. More so, because higher commissions could mean higher transaction fees for the user, and there were often tradeoffs 
between agent profits and financial inclusion objectives.

A study by Alqahtani, Al-Badi and Mayhew [28] in Saudi Arabia that investigated the factors, that made the mobile subscribers reluctant, as well as the factors that made mobile phone users keen to accept mobile transaction. The findings of their study showed that the factors that had the most significant influence on the acceptance and use of mobile transaction in Saudi Arabia were: usability, usefulness, telecommunications infrastructure, security, hacking and fraud, availability, trust, payment gateway, awareness, cost and promotion, privacy, cyber-law, the postal services, government e-readiness, Arabic language support among other factors. Some of these findings in a way are replicated in this study. Just as in Saudi Arabia, the study established challenges caused by factors such as trust issues when it comes to utilization of the technology, security issues as well as fraud. These challenges; trust, security and fraud, requires proper measures if $\mathrm{MNO}$ were to satisfy mobile phone money users.

\subsubsection{Distribution and Services of Mobile Money Service Agents as a Factor}

The other factor which came as a challenge was the existence of few mobile phone money agents in the study area, especially the rural parts. In addition to the few agents available in the rural parts of the study area, the agents always had limited cash and e-float to trade with. Availability of agents as well as both cash and e-floats are some of the facilitating conditions that enhances mobile phone money use. The inadequate or lack of agents, cash as well as e-floats was perceived by mobile phone money users to have led to ineffective service delivery to the users of mobile phone money in the study area. The study further established that, the only days that mobile phone money agents at least had much money and e-float to serve more customers were during market days.

It was equally difficult to find an agent having sufficient money to serve all those withdrawing large sums of money. In most case they would encourage those withdrawing, to do so in small quantities so as to allow them serve many people with the limited money resource that they had and make more profit in return in their perception. A follow up interview with an M-Pesa agent established that this was done intentionally so as to maximize profits with the limited amount. The issue of limited e-float or cash that was available in various outlets was established to have been intentional. It was quite strange in the study area where some mobile money agents used unfair tricks to exploit their customers. These agents had had not recognized that their users' needed to be satisfied, and they therefore resorted to maximization of profits at whatever cost, a factor that needed to be considered for moderation and amendment by MNOs with presence in the study area. The users who required large amounts to withdraw, some were discouraged of withdrawing the much they required and in return, offered amount up to certain threshold dictated by the owner, and were hence forced to obtain the deficit from the next agent. Alternatively some agents might have been motivated by the need to serve many customers, thereby making them dominate the market. Looking at this factor in this perspective indicated that having adequate cash and e-float by mobile phone money agents was another critical facilitating condition positively or negatively.

\subsubsection{Mobile Phone Money Transaction Service Delays}

Delays during transactions using mobile phone money was yet another major concern that a few informants of the study experienced, perceived as a potential hindrance to mobile phone money utilization. Most of the users got irritated when they were forced to wait for long minutes or even hours on the event of transaction delays. Most of the users who had experienced delay in the past preferred to carry out cash transactions as opposed to experiencing delays. Many argued that this could any day be disastrous, especially in case of emergency that would require money urgently. Therefore, to many people, this condition would be a demotivator to comply with mobile phone money innovation or to use. This led to some users and potential users to have subjective view of this innovation, which negatively influenced their behavioural intention to use. The delays experienced when transacting using mobile phone money services to send, receive money, to buy goods or pay bills which also posed as another challenge. This was not specific to any part however; it was cutting across the entire study area, whether urban or rural. This discouraged many users from fully embracing mobile phone money services, especially those who were always impatient.

The delays could be attributed to by a number of factors. They could be as a result of the network strength which is dependent on infrastructural support. Balan, Ramasubbu, Prakobphol, Christin, and Hong, [29] established in work that one disadvantage of mobile money services was that it required infrastructure support from the mobile network operators. Further, payments could not be made if there were no mobile phone reception. Basically, this meant that SMS based payments may not work in remote places with the challenges of connectivity in terms of network. This was similar to the challenge that users at times faced on transaction delays in the study area. This indicated that network connectivity was not that perfect, since there were instances when fluctuations existed that resulted in transaction delays, which was experienced across the entire study area, both rural and urban areas alike sometimes. Balan et al., further, stated that even stormy weather could cause problems to the cellular network infrastructure making it impossible to make SMS-based payments. Cellular network connectivity would therefore be considered as another facilitating condition, as it supports the use of mobile phone money service.

\subsubsection{Traders that Had Embraced Mobile Money Service}

The other factor that was established to influence mobile 
phone money use in the study area was that traders in the area had not embraced, availing mobile phone money option of payment to their customers. Just a handful of traders had this option of payment to offer to their customers and this was perceived by mobile phone users as a hindrance to widespread utilization in the study area. Utilization of mobile phone money by traders therefore was seen to be a kingpin of mobile phone money use, especially with regard to facilitating mobile commerce. This factor became another facilitating condition in ensuring that as many people as possible embraced mobile money in purchase of goods and services. In contrary to the study conducted in Kenya by Nyaga [30], on the impact of mobile money services on the performance of small and medium enterprises in an urban town (Naivasha), Kenya, that established that, mobile phone money had made a significant contribution to the SME sector, in Homa Bay region however, the contribution of mobile phone money to the business community was insignificant. Traders in Homa Bay still relied mostly in cash transaction. In Nyaga's study, majority of the traders relied on it as opposed to the formal banking sector for their day to day transactions and cash handling. Further, Nyaga in his study established that all the informants in his study had a clear understanding of some of the basic functions of mobile money services, unlike what was established in Homa Bay region.

Many traders in the study area still preferred cash transactions over cashless transactions. Mostly, this was due to lack of trust of the mobile phone payment systems. Since this approach of transaction depends on SMS technology, most traders feared that they could become victims in the hands of individuals who may recycle a previous SMS during transaction to defraud them. Also as observation during the study exposed, it was very clear that very few traders had embraced mobile phone payment to be used by their various customers as a means of transaction. This gave rise to yet another variable that is worth including in the study of technology or innovation use. User readiness to use technology should be a factor or variable to consider. In Homa Bay, probably the traders were not ready to use mobile phone money services. The traders who had embraced mobile phone money services in their businesses were mainly those with businesses in urban centers in the study area. Therefore, this became a challenge especially for the users who intended to use mobile phone money payment services in buying goods within the rural communities.

According to Hoofnagle, Jennifer and Li, [31], many challenges remained to the use of new payment systems such as mobile phone money and the very basic challenge was that, mobile payment providers must sell the system to both the sellers and consumers simultaneously. That is, providers must convince the sellers to build infrastructure at the point of sale which would eventually enable payment using mobile payment platform and to succeed, they must persuade enough consumers to frequently use mobile phone payments, that the sellers find the system profitable. This clearly replicates the situation existing in the study area. In certain areas you find a few mobile money users, who would prefer to use the systems, such as it was the case of the rural parts of the study area, yet the sellers/traders did not provide the services in their premises. Whereas there also existed other places where, there were traders/sellers who had the services of mobile phone money in their businesses, but the buys were strongly glued to cash transactions. This further indicated how both the users and the traders were not ready for mobile phone money services as at the time of this study. This therefore calls for a balance in popularizing the technology among the traders/sellers as well as the buyers, which was lacking in the study area.

These factors influencing acceptance and use of mobile phone money services has been used as illustrated in section 3.2.2 in construction of the Extended Theory of Reasoned Action.

\subsection{Constructing and Validating Extended Theory of Reasoned Action}

\subsubsection{Theory of Reasoned Action}

The Theory of Reasoned Action (TRA) has been mostly cited in Information Systems and ICT studies, but mainly to an extent where it set a stage for other theories like Theory of Planned Behaviour (TPB) and Technology Acceptance Model (TAM). This theory originated from social psychology, and other people take it as a special case of the TPB [32]. Fishbein and Ajzen [33] developed TRA to define the links between the beliefs, attitudes, norms, intentions, and behaviors of individuals. TRA assumes that a person's behavior is determined by the person's behavioral intention to perform it, and the intention itself is determined by the person's attitudes and his or her subjective norms towards the behavior. The subjective norm refers to the person's perception that most people who are important to him think he should or should not perform the behavior in question [33].

This TRA was introduced in an effort to understand the relationship between attitude and behaviour. It attempts to explain the relationship between beliefs, attitudes, intentions and behaviour. According to TRA, the most accurate determinant of behaviour is behavioural intention. The direct determinants of people's behavioural intentions are their attitudes towards performing the behaviour and the subjective norms associated with the behaviour. Attitude is determined by a person's beliefs about the outcomes or attributes of performing a specific behaviour, weighted by evaluations of those outcomes or attributes. The subjective norm of a person is determined by whether important referents approve or disapprove of the performance of a behaviour (that is, normative beliefs), weighted by the person's motivation to comply with those referents [34]. The relationships of the constructs of TRA are summarized in Figure 1. 


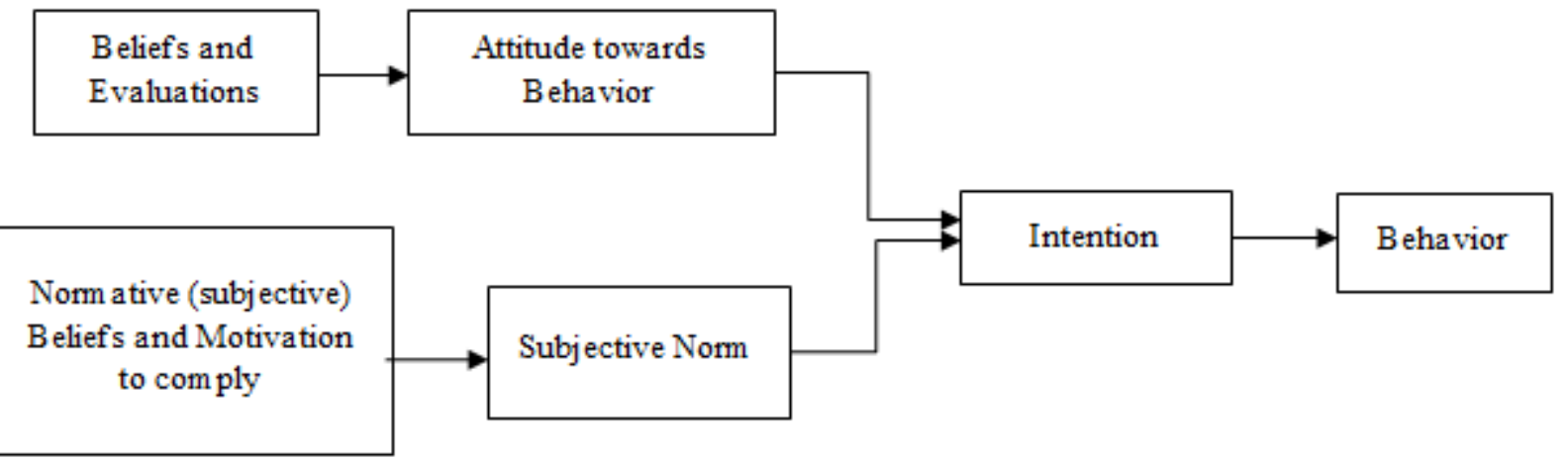

Source: Fishbein, \& Ajzen [35]

Figure 1. Theory of Reasoned Action

\subsubsection{Constructing Extended Theory of Reasoned Action}

TRA is therefore a better theory for Information Systems studies, over other theories, especially considering the determinants of behavior. To make it even stronger, it was necessary to introduce more determinants. To make TRA even more conducive for a study similar to this, there is need to incorporate other direct and indirect determinants to behaviour, which give birth to Extended Theory of Reasoned Action. In extending the TRA, the determinants of behaviour included are behavioural intention, facilitating conditions and user readiness to use new innovation. The direct determinants of people's behavioural intentions included are their attitudes towards performing the behaviour, awareness of innovation, social pressure (networks and interactions), and the subjective norms associated with the behaviour. While attitude is determined by a person's beliefs about the outcomes or attributes of performing a specific behaviour, weighted by evaluations of those outcomes or attributes, the subjective norm of a person is determined by whether important referents approve or disapprove of the performance of a behaviour (normative beliefs), weighted by the person's motivation to comply with those referents and the social pressure/influence (networks and interaction) resulting from those individuals influencing the user directly or indirectly.

Figure 2 illustrates the varied determinants that build up the extended Theory of Reasoned Action.

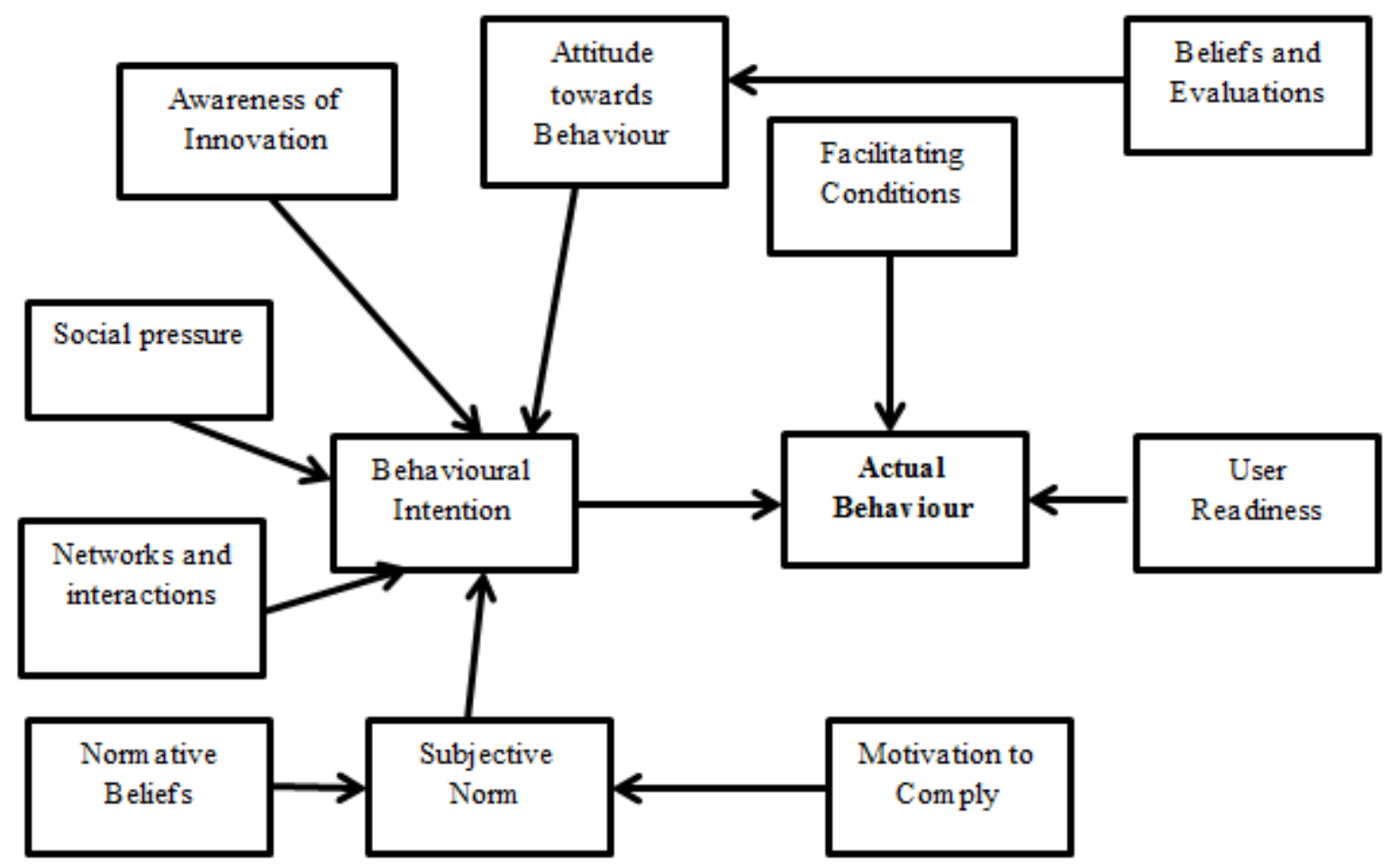

Source: Own conceptualization (2017)

Figure 2. Basic Determinants of behaviour 
The model in figure 2, above can be simplified and classified under direct determinants and indirect determinants, as illustrated in figure 3.

Figure 3 illustrates direct and indirect determinants that build up the extended Theory of Reasoned Action.

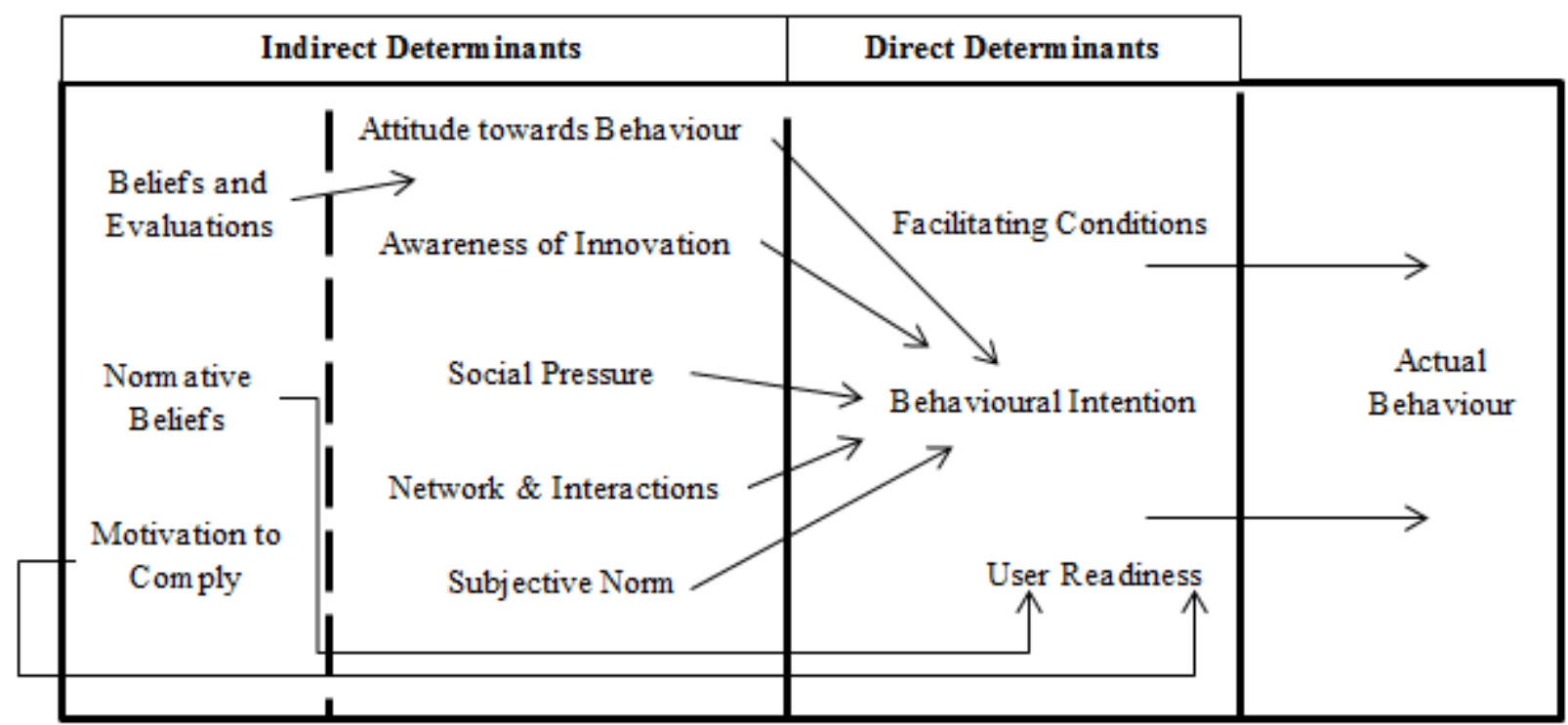

Source: Own conceptualization (2017)

Figure 3. Direct and Indirect determinants building Extended Theory of Reasoned Action

A study conducted in China by Yang, Lu, Gupta, Cao, and Zhang [36], established that behavioral beliefs in combination with social influences and personal traits are all important determinants for technology innovation adoption and use. The study further established that, mostly in the rural part of the study area, remittance was more on receiving money that were sent by the relatives of mobile phone users who lived and worked in Nairobi and other major towns in Kenya, and others who lived and worked in foreign countries than users sending money. This could be attributed to social pressure/influence (networks and interactions) emanating from friends and relatives who were already using technology over other media for sending and receiving money, which this study also established to influence directly, the behavioural intentions to use technology. It is therefore very important to consider Social Pressure/Influence, as a factor or variable when conducting any study on technological innovation and as such, it can be included in TRA in developing the extended TRA. Social pressure would always influence either positively or negatively, behavioural intention to use mobile money innovation, which indicates that it has some practical implication as it influence technology use.

The study further established that a greater majority, especially the rural poor communities were not aware of the existence of certain innovations, even those that were available in the gadgets that they already possessed or within their mobile phones. It was therefore not more practical to conduct study on use of a technology or innovation that the potential users were not aware of its existence. For that reason, it is quite important to include Awareness of Innovation as a variable when conducting studies on technological innovation. Awareness or non-awareness of innovation or technology in itself could be the contributing factor in technology use.

From the study, it was established that TRA as it was originally would have adverse implication in IS studies dealing with technology use. This is as a result of failure to capture all the significant determinants that influence greatly, technology use. However, the shortcomings of the Original TRA could be minimized, by incorporating factors such as; users' awareness of technology, social pressure/influence emanating from friends or colleagues, Facilitating conditions as well as user readiness to engage actively the new technology. The implication of applying the new version of TRA with the above identified determinants, would address a number of shortcomings presented by the original TRA. Incorporating these determinants result the extended Theory of Reasoned Action shown in figure 4.

Figure 4 illustrates the extended Theory of Reasoned Action. 


\section{Facilitating Conditions}
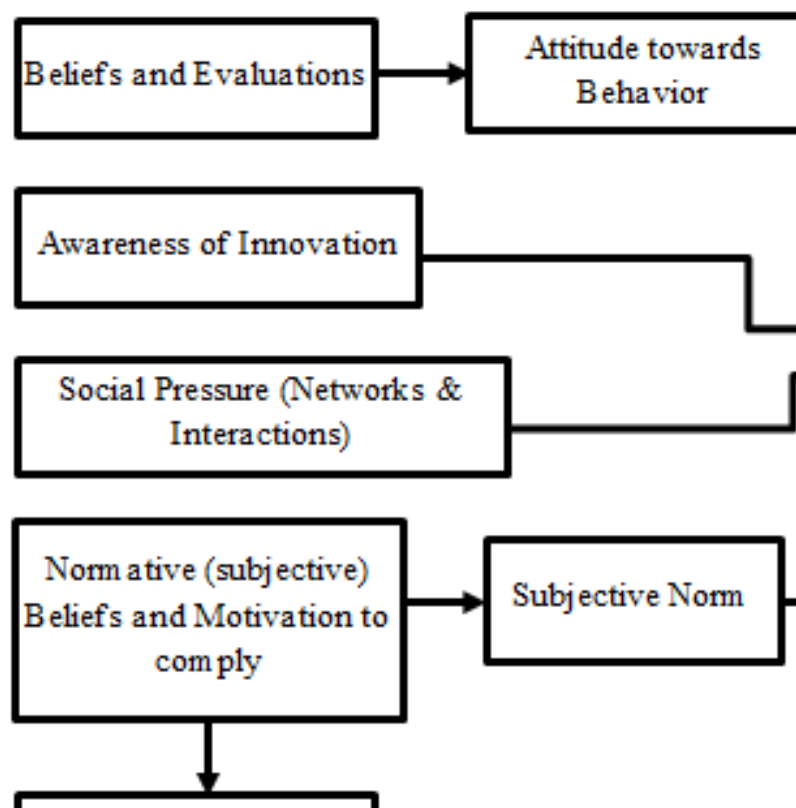

User readiness

Subjective Norm

Figure 4. Extended Theory of Reasoned Action

\subsubsection{Validation of Extended Theory of Reasoned Action Model}

The study resulted into a model in figure 4, the extended Theory of Reasoned Action. The model has both direct determinants and indirect determinants being the determinants of behavior, which include; behavioural intention, facilitating conditions and user readiness to use new innovation. The direct determinants of people's behavioural intentions were established in the study as users' attitudes towards performing the behaviour, awareness of innovation, social pressure (networks and interactions), and the subjective norms associated with the behaviour.

This model was validated using Pearson's correlation to establish the association that existed between mainly the factors that were added to TRA to arrive at the extended TRA. To obtain data for validation, a one paged questionnaire was distributed to 50 participants (New participants that never participated in the initial study), and this questionnaire contained the factors that influence mobile money use that are the construct of the Extended TRA.

Table 1. Correlation on the constructs of Mobile Money Use

\begin{tabular}{|c|c|c|c|c|c|c|c|}
\hline & $\begin{array}{c}\text { Mobile Phone } \\
\text { Money Use }\end{array}$ & $\begin{array}{l}\text { Facilitating } \\
\text { Conditions }\end{array}$ & $\begin{array}{l}\text { Belief on the } \\
\text { Benefits }\end{array}$ & $\begin{array}{c}\text { Awareness of Mobile } \\
\text { Money elements }\end{array}$ & \begin{tabular}{|c|} 
Influence by \\
Friends
\end{tabular} & User Readiness & $\begin{array}{c}\text { User Intention } \\
\text { to use }\end{array}$ \\
\hline Mobile Phone Money Use & 1 & $.725 * *$ & $.310^{*}$ & $.578 * *$ & .124 & $.302^{*}$ & $.341^{*}$ \\
\hline Facilitating Conditions & $.725 * *$ & 1 & .161 & .181 & .093 & $.483 * *$ & $.325^{*}$ \\
\hline Belief on the Benefits & $.310^{*}$ & .161 & 1 & .191 & .115 & .096 & $.310^{*}$ \\
\hline $\begin{array}{c}\text { Awareness of Mobile Money } \\
\text { elements }\end{array}$ & $.578 * *$ & .181 & .191 & 1 & $.642 * *$ & $.349^{*}$ & $.309^{*}$ \\
\hline Influence by Friends & .124 & .093 & .115 & $.642^{* *}$ & 1 & .134 & .196 \\
\hline User Readiness & $.302 *$ & $.483 * *$ & .096 & $.349^{*}$ & .134 & 1 & $.449^{* *}$ \\
\hline User Intention to use & $.341 *$ & $.325 *$ & $.310^{*}$ & $.309^{*}$ & .196 & $.449 * *$ & 1 \\
\hline
\end{tabular}

*. Correlation is significant at the 0.05 level (2-tailed).

**. Correlation is significant at the 0.01 level (2-tailed).

Source: Field Data, 2017 
Facilitating Conditions had strong association with mobile phone money use. This is indicated by a strong positive correlation at $r=0.725$. This is an indication that facilitating condition is an important determinant to mobile phone money use.

User beliefs on the benefits of mobile money was yet another construct that was established to have a positive correlation to mobile money use. Even though it was a weak positive correlation at $r=0.310$. This is a significant association that cannot be ignored when establishing determinants to mobile money use.

Awareness of mobile money elements is another factor forming the construct of the extended TRA that was considered in validation. Awareness of the technology as illustrated in the model, indirectly affect the actual use. However, it directly influence behavioral intention to use. From the data analyzed, there was a moderate positive correlation at $r=0.309$. Further, when awareness of innovation or technology was taken to have a direct influence on the actual use of innovation, the data still portrayed a moderate positive correlation at $r=0.578$. Based on this information, Awareness of technology or innovation was established and validated to be effective construct of the proposed model.

Influence by friends and Social Pressure had a weak positive correlation when considered to influence actual use directly or indirectly through influencing behavioral intention. When social pressure was considered to influence actual use directly, the result yielded from the data collected was a weak positive correlation at $r=0.124$, whereas when considered to influence behavioral intention, then the correlation was still a weak positive one at $r=0.196$.

User readiness was another construct that was proposed in the model to influence technology use. User readiness directly influences technology use. On validation through correlation, the data established a weak positive correlation existing between user readiness and actual use at $r=0.302$.

Other constructs like attitude towards behavior, Normative (subjective) Beliefs and Motivation to comply as well as subjective norm were not considered for validation as they had been considered valid, having been borrowed from Theory of Reasoned Action (TRA). Therefore based on the correlation analyses that are further summarized in table 1 , the model has been validated to be conducive in conducting studies on technology and innovation use.

\section{Conclusions}

It was established that TRA as it was originally would have adverse implication in IS studies dealing with technology use. This was as a result of failure to capture all the significant determinants that influence greatly, technology use. However, the shortcomings of the
Original TRA could be minimized, by incorporating factors such as; users' awareness of technology, social pressure/influence emanating from friends or colleagues, Facilitating conditions as well as user readiness to engage actively the new technology. The implication of applying the new version of TRA with the additional determinants, would address a number of shortcomings presented by the original TRA.

\section{REFERENCES}

[1] Ajzen, I. \& Fishbein, M. (1980). Understanding Attitudes and Predicting Social Behavior. Englewood Cliffs, NJ, Prentice-Hall Inc.

[2] Fishbein, M. (1968). An investigation of relationships between beliefs about an object and the attitude towards that object. Human Relationships, 16, 233-240.

[3] Pope, C., \& Mays, N. (2000). Qualitative Research in Health Care. London: BMJ Books.

[4] Denzin, N. K. \& Lincoln (2011). The Sage Handbook of Qualitative Research. Sage Publications: USA.

[5] Iacono, J. Brown, A., \& Holtham, C., (2009). Research Methods - a Case Example of Participant Observation: Electronic Journal of Business Research Methods Volume 7 Issue 12009 (39 - 46)

[6] Myers, M.D. (1999). 'Investigating Information Systems with Ethnographic Research' in Communications of the AIS, Vol. 2, Article 23 pp. 1-20

[7] Reeves, Kuper and Hodges. (2008). Qualitative research methodologies: ethnography. British Medical Journal. 337:a1020.

[8] Homa Bay CIDP, (2013). The First County Integrated Development Plan 2013 - 2017

[9]. KNBS, (2014b). Single and Grouped Ages in years by County and District, Kenya National Population and Housing Census of 2009

[10] KNBS, (2014a). Access to Mobile Phone Service by County and District, Kenya National Population and Housing Census of 2009. (Accessed on $13^{\text {th }}$ July, 2015, from: http://www.knbs.or.ke/index.php?option=com phocadownl oad\&view=category \&download=414:access-to-mobile-pho ne-service-by-county-and-district\&id=99:detailed-census-re sults\&Itemid $=639$ )

[11] Bailey, C. A., (2007). A Guide to Qualitative Field Research. ( $2^{\text {nd }}$ Edition). London: Pine Forge Press.

[12] Amin, E. M., (2005). Social Science Research, Methodology and Analysis. Kampala: Makerere University.

[13] Flick, U. (1998). An introduction to qualitative research: Theory, method, and applications. London: Sage.

[14] Morse, J. M. (1995). The significance of saturation. Qualitative Health Research, 5, 147-149. 
[15] Strauss, A., \& Corbin, J. (1990). Basics of qualitative research: Grounded theory procedures and techniques. Newbury Park, CA: Sage.

[16] Kothari, C.R., (2003), Research Methodology-Methods and Techniques, New Delhi, Wiley Eastern Limited.

[17] Kombo, D. \& Tromp, D (2006). Proposal and Thesis: An introduction. Nairobi. Pauline's Publication East Africa.

[18] Quinn, M. (2002). Qualitative research and evaluation methods. Minesota: Sage Publications

[19] DeWalt, K., \& DeWalt, B. (2011). Participant observation: A guide for fieldworkers ( $2^{\text {nd }}$ Edition.). Lanham, MD: AltaMira.

[20] Koester, S., \& Hoffer, L., (1994). Indirect sharing: Additional risks associated with drug injection. AIDS and Public Policy 1994, 9(2), 100-105.

[21] Ajzen, I. \& Fishbein, M. (1980). Understanding Attitudes and Predicting Social Behavior. Englewood Cliffs, NJ, Prentice-Hall Inc.

[22] Suri, T. \& William, J. (2008). The performance and Impact of M - PESA: Preliminary Evidence from a Household Survey. Unpublished Paper

[23] Government of Kenya (2003). Economic Survey 2003. Central Bureau of Statistics Government Printers, Nairobi.

[24] Kikulwe, E.M., Fischer, E. \& Qaim, M. (2013). Mobile money, market transactions, and household income in rural Kenya: GlobalFood Discussion Papers.

[25] Mallat, N. (2007). Exploring Consumer Adoption of Mobile Payments. A Qualitative Study. The Journal of Strategic Information Systems, 16 (4), 413-432.

[26] Porteous, D. (2007). Just how transformational is m-banking? Retrieved 10 August, 2015, from

[27] Citibank (2012), 10 Ways to Accelerate Mobile Money: USAID-Citi Mobile Money Accelerator Alliance.
[28] Alqahtani M. A, Al-Badi A. H., \& Mayhew P. J., (2014) Exploratory Study of M-Transaction: User's Perspectives. The Electronic Journal on Information Systems in Developing Countries. 60, 7, 1-22.

[29] Balan, R. K., Ramasubbu, N., Prakobphol, K., Christin, N., \& Hong, J. (2009). mFerio: the design and evaluation of a peer-to-peer mobile payment system. MobiSys '09 Proceedings of the 7th International Conference on Mobile Systems, Applications and Services.

[30] Nyaga, K. M., (2014). The Impact of Mobile Money Services On the Performance of Small and Medium Enterprises in an Urban Town in Kenya. The Academic Commons: The Official Institutional Repository of $K C A$ University.

[31] Hoofnagle, C. J., Jennifer M. \& Li, U.S., (2012). Mobile Payments: Consumer Benefits \& New Privacy Concerns: BCLT Research Paper April 24, 2012

[32] Ajzen, I., (2010). The Theory of Planned Behavior, Viewed from: http://www.people.umass.edu/aizen/tpb.html, on February 16, 2016.

[33] Fishbein, M., \& Ajzen, I. (1975). Beliefs, attitude, intention, and behavior: An introduction to theory and research. Reading, MA: Addison-Wesley.

[34] Montano, D. E. \& Kasprzyk, D. (2002). The theory of reasoned action and the theory of planned behaviour. In K. Glanz, B. K. Rimer, \& F. M. Lewis (Eds.), Health behaviour and health education: Theory, research and practice (pp. 67 98). San Francisco: Jossey Bass.

[35] Fishbein, M., \& Ajzen, I., (2010). Predicting and changing behavior: The reasoned action approach. New York: Psychology Press (Taylor \& Francis).

[36] Yang, S., Lu, Y., Gupta, S., Cao, Y. and Zhang, R. (2012) Mobile Payment Services Adoption across Time: An Empirical Study of the Effects of Behavioral Beliefs, Social Influences, and Personal Traits, Computers in Human Behavior, 28, 1, 129-142. 